\title{
Study Deformability Ecological Steel (41Cr4)
}

\begin{abstract}
CARMEN OTILIA RUSANESCUㄴ, MARIN RUSANESCU2*, FLORINA VIOLETA ANGHELINA ${ }^{3 *}$, ILEANA NICOLETA POPESCU³
${ }^{1}$ University Politehnica, Faculty of Biotechnical Systems Engineering, 313 Splaiul Independentei, 060042, Bucharest, Romania 2Valplast Industrie, 9 Preciziei Blvd., 062202, Bucharest, Romania

${ }^{3}$ Valahia University of Targoviste, Faculty of Materials Engineering and Mechanics, 13 Sinaia Alley, 130004, Targoviste, Romania

In this paper is studied the hot plastic deformability (plasticity and resistance to deformation) for the lowalloyed steel of heat treatment for mechanical engineering in two ways: compression and tension. Groups of low alloy steels is very important in terms of quality and quantity, the products of these steels have developed internal and external market. The plasticity variation were plotted with the temperature and it was established that the plasticity of the steel increases in the range $700-1200^{\circ} \mathrm{C}$, then decreases as a result of the firing of the grain boundaries, for the bars obtained from ingot and continuous cast blown it was noticed that the plasticity values are very close. Deformation resistance decreases as the temperature increases. The finest granulation was obtained for a final plastic deformation temperature of $800^{\circ} \mathrm{C}$ and a minimum degree of deformation of $45 \%$.
\end{abstract}

Keywords: deformability, discharge traction, austenite grain, compression

Groups of low alloy steels is very important in terms of quality and quantity, the products of these steels have developed internal and external market. Hot deformability of metallic materials is characterized by resistance to deformation and ductility $[1,3,7,10,12,14,17]$.

A friendly technology with the environment which consists in the elaboration of carbon steels through specific proceedings to powder metallurgy has in view the contribution of methane gas in iron powders at the same time with sintering. This technology is advantageous from various points of view: the final product is a part which does notneed afterward processing with solid waste result and therefore the specific energy consume is lower, the wear and corrosion behavior is similar to that of classic steels and better than that of sintered steels obtained through mixing iron and graphite; the obtained steels is also a recycling material $[5,6,9]$. The carbon steel obtained through this new technology is an ecomaterial, energy consumption and reduced environmental pollution $[4,8$, 15]. From an environmental perspective, the steel is durable and $100 \%$ recyclable $[1,11,13,16,19-23]$. It is useful to use environment-friendly materials to reduce pollution [ 2 , $6,16]$.

\section{Experimental part}

Materials and methods

Hot plastic deformability (plasticity and deformation resistance) was studied by two methods: hot compression(hot discharge) and hot traction. The sample for the compression and traction was fabricated from billet and bars manufactured by two methods: ingot steel and continuous casting steel.

Hot plastic deformability was studied by two methods: hot compression and hot traction.

a) Study of hot plastic deformability by hot compression Specimens with the initial dimensions: $D=16 \mathrm{~mm}$ (diameter) and $\mathrm{h}=24 \mathrm{~mm}$ (height) were heated between $700-1200^{\circ} \mathrm{C}$ in an electric furnace and were impacted by a weight of 115 daN, which fell down from a high of $2.2 \mathrm{~m}$.

The calculation of the damage of the tubular specimens to static loading, depending on the geometry and the position of the crack, was determined according to [19].
The plastic deformation rate is:

$$
\varepsilon=\frac{h_{0}-h_{1}}{h_{0}} \cdot 100[\%]
$$

where: $h, h$ are the initial and the final heights of samples.

Deformation resistance $R_{c}$ was calculated as follow:

$$
\mathrm{R}_{c}=\frac{\mathrm{GH} \eta}{\left(1+\frac{1}{3} \cdot f \frac{d_{1}}{h_{1}}\right) \cdot \mathrm{v} \cdot \varepsilon}\left[\mathrm{daN} / \mathrm{mm}^{2}\right]
$$

where:

$\mathrm{G}=115$ [daN] is the massic force of the impact load;

$\eta=0.9$ - efficiency of utilization;

$f=0.3$ - coefficient of friction

$d_{1}, h_{1}$ - final dimension (of the deformed sample compression); $V$ - the sample's volume; $H$ - the sample's height; $\varepsilon$ - deformation degree.

The diameter $\left(d_{1}\right)$ of the deformed sample will be calculated as following:

$$
\begin{aligned}
& \frac{\pi \mathrm{d}^{2} 0}{4} \cdot \mathrm{h}_{0}=\frac{\pi \mathrm{d}^{2}{ }_{1}}{4} \cdot \mathrm{h}_{1} \\
& \mathrm{~d}_{1}=\mathrm{d}_{0} \sqrt{\frac{\mathrm{h}_{0}}{\mathrm{~h}_{1}}}[\mathrm{~mm}]
\end{aligned}
$$

Finally, the diagrams of the deformation resistance and plasticity, as a function of temperature, were drawn: $R_{c}=$ $\mathrm{f}(\mathrm{t}) ; \varepsilon=\mathrm{f}(\mathrm{t})$.

\section{b) Study of hot plastic deformability by hot traction tests}

For tests it was used a traction machine ( $200 \mathrm{KN})$ with an electric furnace mounted on. Elongation after fracture, as a function of plasticity, was computed as follows:

$$
\mathrm{A}=\frac{1_{1}-1_{0}}{1_{0}} \cdot 100 \quad[\%]
$$

where: $I_{0}=100 \mathrm{~mm}$ is the initial length of the calibrated area of the samples; $I_{1}$ - length of the calibrated area of the samples (after fracture).

Ultimate strength, $R_{r}$ was computed as follows (tensile strength): 


$$
\mathrm{R}_{\mathrm{r}}=\frac{\mathrm{F}_{\max }}{\mathrm{S}} \quad\left[\mathrm{daN} / \mathrm{mm}^{2}\right]
$$

where: $F_{\text {max }}$ - maximum force indicated at the tensile testing machine [daN]; $\mathrm{S}$ - initial section of the specimen in calibrated area [ $\left.\mathrm{mm}^{2}\right]$.

Finally, the curves drawn were: Elongation after fracture as a function of temperature: $A=f(t)$; Ultimate strength (tensile strength) as a function of temperature: $R_{r}=f(t)$.

\section{Results and discussions} 1).

The chemical composition of steel was as follows (table

The $40 \mathrm{Cr} 10$ hot plastic deformation regime is similar to that applied to other poorly alloyed steel grades of improvement: $40 \mathrm{BCr} 10,34 \mathrm{MoCr} 11,42 \mathrm{MoCr} 11$, $51 \mathrm{VMnCr} 11,40 \mathrm{CrNi12}, 31 \mathrm{Mn} \mathrm{CrSi}, 36 \mathrm{MnCrSi} 13,30$ MoCrNi20, 34MoCrNi16 [10, 12].

\section{Macro structural analysis}

Figure 1 shows the layout of a sample macrostructural forged billet $\Phi 30 \mathrm{~mm}$ section of $140 \mathrm{~mm} \times 140 \mathrm{~mm}$ (billets rolled ingot $5 \mathrm{t}$ ).

Figure 2 shows the macrostructural $[4,17,18,20,21]$ aspect of a sample of $20 \mathrm{~mm} \Phi$ bar made of continuous cast floraison.

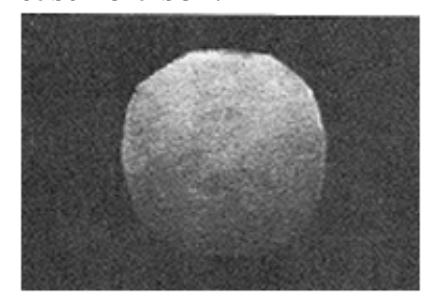

Fig. 1 structure macroscopic for steel $41 \mathrm{Cr} 4$ (bar made of ingot)

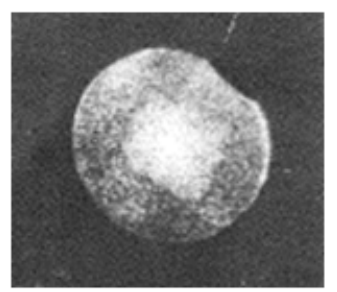

Fig. 2 Macroscopic appearance steel $41 \mathrm{Cr} 4$ (Blum made from continuously cast bar)

According to STAS 791-88 and SREN 10083 / 1-92, the steel is correspondingly macroscopically because it does not show flakes, retouich, porosity, and cracks. [8, 9, 11, $12,21,22]$.

\section{Microstructural analysis}

a)austenitic grain hereditary STAS 791-88 prescribes score $5 . . .8$ austenitic grain hereditary.

SREN 10083/1-92 prescribed for hereditary austenitic grain score 5 or finer $[8,9,11,12,21]$.
The two batches were fine grain steel as hereditary austenitic grain size determined by the attack grain (STAS 5490-80) is the following:

- Made from ingot bar: grain score 8;

- Sampling of billets with section $100 \mathrm{~mm} \times 100 \mathrm{~mm}$ (Blum rolled continuously cast billets) scoring seven grains Samples of $20 \mathrm{~mm} \Phi$ bar made of continuous cast Blum: scoring nine grains (fig. 3 ).

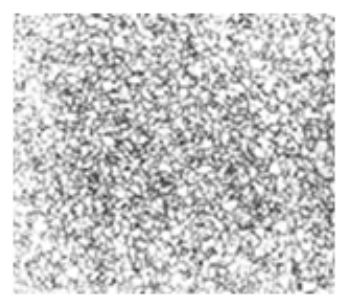

Fig. 3 Austenitic grain hereditary aspect

$\mathrm{x} 100$ picric acid attack

a) Appearance micro structural

$\Phi 26 \mathrm{~mm}$ bars made of ingots and the $\Phi 20 \mathrm{~mm}$ made from continuously cast Blum, suffered after rolling a spheroidization annealing, as a result, the appearance is that of figure 4 (structure consists of ferrite, pearlite lamellar and globular - $80 \%$.

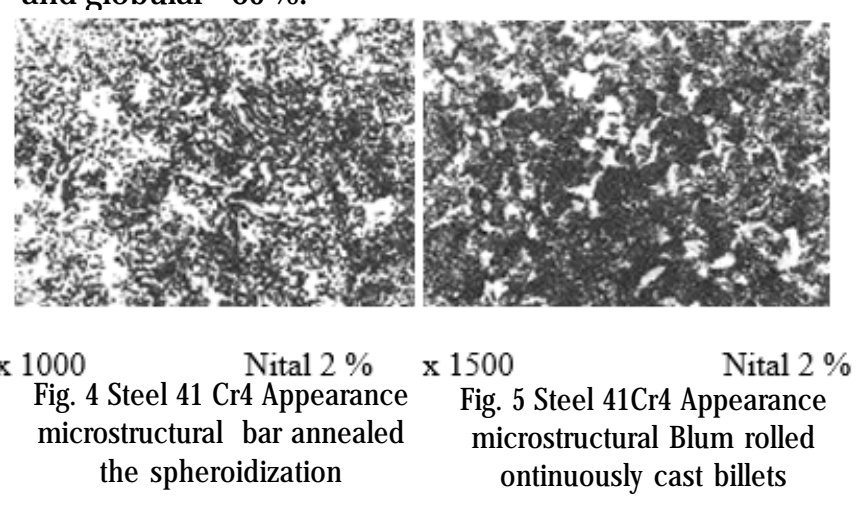

Figure 5 shows the appearance of micro rod with section $100 \mathrm{~mm} \times 100 \mathrm{~mm}$ blum rolled continuously cast: are seen lamellar ferrite and pearlite. To highlight the grain (former austenite grain) surface prepared for metallographic analysis was attacked with a saturated solution of picric acid in water (joint attack grain). Measurements were performed on a metallographic microscope with ocular gradually to increase $x 100$. The average diameter of the grains was determined in longitudinal and transverse direction, and based on his average grain area was located (S) [15-17].

Figure 6 shows some steel microstructures for $41 \mathrm{Cr} 4$, picric acid attack, magnification x 100 (size of former austenite grains depending on the temperature, the degree of deformation $\varepsilon=45 \%$ ).

Table 1

CHEMICAL COMPOSITION OF THE STEEL WERE AS FOLLOWS

\begin{tabular}{|c|c|c|c|c|c|c|c|c|c|}
\hline \multirow[t]{2}{*}{ Steel STAS } & \multicolumn{9}{|c|}{ Chemical composition, \% } \\
\hline & $\mathrm{C}$ & $\mathrm{Si}$ & $\mathrm{Mn}$ & $\mathrm{P}$ & S & $\mathrm{Cr}$ & $\mathrm{Ni}$ & $\mathrm{Cu}$ & $\mathrm{Al}$ \\
\hline Ingot steel & 0.42 & 0.24 & 0.62 & 0.02 & 0.020 & 1.10 & 0.06 & 0.10 & 0.012 \\
\hline $\begin{array}{c}\text { Continuous casting } \\
\text { steel }\end{array}$ & 0.39 & 0.31 & 0.80 & 0.02 & 0.020 & 0.91 & 0.07 & 0.10 & 0.02 \\
\hline $\begin{array}{l}\text { SR EN } 10083 \\
41 \mathrm{Cr} 4\end{array}$ & $0.38-0.45$ & $\begin{array}{l}\max . \\
0.40\end{array}$ & $\begin{array}{l}0.60- \\
0.90\end{array}$ & $\begin{array}{l}\max \\
0.025\end{array}$ & $\begin{array}{l}\max \\
0.025\end{array}$ & $\begin{array}{l}0.90- \\
1.20\end{array}$ & - & - & - \\
\hline
\end{tabular}




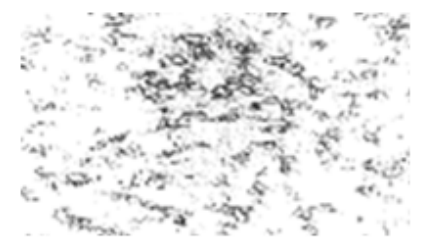

a) $\mathrm{t}=750^{\circ} \mathrm{C} \varepsilon=45 \%$

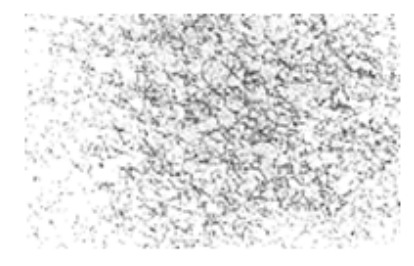

b) $\mathrm{t}=800^{\circ} \mathrm{C} \varepsilon=45 \%$ c) $\mathrm{t}=1200^{\circ} \mathrm{C} \varepsilon=45 \%$

Fig. 6 Microscopic appearance of former austenite grains (x 100, picric acid attack)

From figure 6 observe that if the $750^{\circ} \mathrm{C}$ strain recrystallized grains started but not finished recrystallization process. At $800^{\circ} \mathrm{C}$ recrystallization took place entirely. At $1200^{\circ} \mathrm{C}$, the surface grains grew and began the oxidation inclusions marginal.

\section{Plasticity study}

The plasticity of metal materials represents their ability to deform plastically, changing their shape and dimension under the action of the external force, maintaining their integrity at discharge was in the range $\varepsilon=250-300 \mathrm{~s}^{-1}$. In table 3 presents the results of hot tensile test (specimen $\Phi 10 \times 100 \mathrm{~mm}$ ) of specimen deformation rate was $\varepsilon=$ $0.5 \times 10^{-3} s^{-1}$.

Table 2 shows the results of testing hot discharge, no evidence was not cracked. Average speed of deformation at discharge was in the range $\varepsilon=250-300 \mathrm{~s}^{-1}$.
Average speed of deformation at discharge was in the range $\varepsilon=250-300 \mathrm{~s}^{-1}$

Table 3 shows the results of the hot traction tests (specimen $\Phi 10 \times 100 \mathrm{~mm}$ ); average speed of deformation to discharge the specimen was $\varepsilon=0.5 \mathrm{x}$ $10^{-3} \mathrm{~s}^{-1}$.

Variation of the plastic deformation resistance at fracture $\left(R_{r 1}\right)$ depending on temperature for steel $41 \mathrm{Cr} 4$ temperature bar obtained from ingot, resistance at fracture $R_{r 2}$ for bar obtained from continuous casting bloom.

The charges were cast as follows: charge nr. 1 (table1) in billets with the average section $600 \mathrm{~mm} \times 600 \mathrm{~mm}$; charge nr. 2 (table 1) in blums.

The tables were made for $26 \mathrm{~mm}$ bars made by rolling, the raw material being the ingot;

Bars $\varnothing 20 \mathrm{~mm}$ are made by lamination, the raw material being continuous blown continuous bloom $\varnothing 20 \mathrm{~mm}$ realized bybloom rolling

As on can see from table 2 and 3 , for $41 \mathrm{Cr} 4$ steel, plasticity directly increased by temperature increase from $700^{\circ} \mathrm{C}$ to $1200^{\circ} \mathrm{C}$. Cause: when steel is heated, it receive a heat input causing an increase of the thermal oscillating of the atoms around their equilibrium positions; in this situation, the applying of the external deformation forces will produce a shading plan process in the planes of the atomic maximum density for much lower stresses. Over $1250^{\circ} \mathrm{C}$ it will occur the process of the grain limits burning, and the plasticity will decrease (table 3). As shown in table 2 and 3 , plasticity of the billet is lower than the bars because primary structure (casting structure) was not destroyed; the plasticity values of the rolled bars are very closed, with no relation to the casting way of steel. By the deformation of the billet $100 \mathrm{~mm} \times 100 \mathrm{~mm}$ as bar $\varnothing 20 \mathrm{~mm}$ increase the structural homogeneity from the point of view of size, geometry of grains, chemical composition, mechanical properties and repartitions inclusions of; the more

\begin{tabular}{|l|l|l|l|l|l|l|l|l|l|l|l|}
\hline$T^{\text {UC }}$ & 700 & 750 & 800 & 850 & 900 & 950 & 1000 & 1050 & 1100 & 1150 & 1200 \\
\hline$R_{\mathrm{c} 1 \mathrm{~d} a N / m^{1}}$ & 52.5 & 40.6 & 36.8 & 32.4 & 30.5 & 28.6 & 24.2 & 21.2 & 19.5 & 18.6 & 18 \\
\hline $\mathrm{R}_{\mathrm{s} 2} \mathrm{daN} / \mathrm{mm}^{2}$ & 46.6 & 36.2 & 32.2 & 28 & 26.2 & 24.4 & 21.5 & 18.8 & 17.2 & 16.2 & 15.5 \\
\hline$\varepsilon_{1}$ & 70.0 & 72.5 & 74.5 & 76.5 & 78.5 & 80 & 82 & 83.5 & 85.0 & 85.5 & 86 \\
\hline$\varepsilon_{2}$ & 73.0 & 74.7 & 76.3 & 77.5 & 79.6 & 82.2 & 84.4 & 85.5 & 87.2 & 88.4 & 89.4 \\
\hline
\end{tabular}

Table 2

RESULTS OF THE HOT DISCHARGE ATTEMPTS FOR STEEL 41Cr4

where: $\varepsilon_{1}$ - the degree of deformation by hot discharge for bars made by rolling, the raw material being

the ingot; $\varepsilon_{2}$ - the degree of hot-rolled deformation for bars made by lamination, the raw material being continuously

cast blown; $\mathrm{R}_{s 1}$ - Resistance to hot-forming deformation for bars made by rolling, the raw material being ingot;

$R_{s 2}$ - Resistance to deformation for rolled bars, the raw material being continuously cast blown.

\begin{tabular}{|l|c|c|c|l|l|l|l|l|l|l|l|}
\hline$T\left[{ }^{\circ} \mathrm{C}\right]$ & 700 & 750 & 800 & 850 & 900 & 950 & 1000 & 1050 & 1100 & 1150 & 1200 \\
\hline$R_{51} \mathrm{daN} / \mathrm{mm}^{2}$ & 23 & 12.2 & 6.4 & 5.5 & 4.6 & 3.8 & 2.8 & 2.2 & 2 & 1,6 & 1.5 \\
\hline$A_{1} \%$ & 17 & 19 & 20 & 27 & 32 & 36 & 40 & 44 & 49 & 54 & 60 \\
\hline$R_{52} \mathrm{daN} / \mathrm{mm}^{2}$ & 24.3 & 12.9 & 8.8 & 7 & 5.7 & 4.6 & 3.9 & 3.1 & 2.5 & 1,9 & 1.4 \\
\hline$A_{2} \%$ & 22 & 26 & 28 & 36 & 42 & 45 & 49 & 54 & 58 & 63 & 69 \\
\hline
\end{tabular}

Table 3

RESULTS OF TENSILE TEST FOR STEEL HOT $41 \mathrm{Cr} 4$

where: $A_{1}$ - Elongation at tensile breaking for bars made by rolling, the raw material being the ingot;

$A_{2}$ - Elongation at tensile breaking for bars made by lamination, the raw material being continuously cast blown;

$R_{s 1}$ - tensile strength of bars made by rolling, the raw material ingot; $R_{r 2}$ - tensile strength of bars made 
homogeneous is the structure, the lower are the supplementary stresses so the plasticity is greater.

In tables 2 and 3 it is shown the variation of the plastic deformation as a function of temperature for the $41 \mathrm{Cr} 4$ steel; at compression it was determined the deformation resistance $R_{c}$ and for tensile, ultimate strength $R_{r}$. The samples for compression and tensile were cut from: $\varnothing 26$ $\mathrm{mm}$ rolled bar, from ingot; Rod with $\varnothing 20 \mathrm{~mm}$ rolled from continuous casting bloom.

As shown in tables 2 and 3 , the hot plastically resistance decrease while temperature increase (between 700 - 1200 $\left.{ }^{\circ} \mathrm{C}\right)$, because, thermal oscillation amplitude increase by heating the atoms; the obtained values are close for the rolled steel obtained from continuous casting billet and, respectively from ingot.

The deformation resistance is the opposing resistance of the metallic materials to the plastic deformation in the given conditions (temperature, speed and deformation degree and the stresses state). Metallic material will suffer hot deformation as easier as its deformation resistance is lower [2].

In figure 7 is shown in cross-section the appearance of a test piece of $16 \times 24 \mathrm{~mm} \Phi$ discharge, untried to heat treatment. Figure 8 shows the discharge specimen, tested at $700^{\circ} \mathrm{C}$ with the deformation degree $\varepsilon=70 \%$. Figure 9 shows the traction specimen, broken at $800^{\circ} \mathrm{C}$.

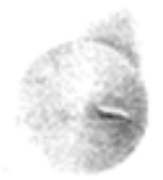

Fig. 7 Discharge specimen

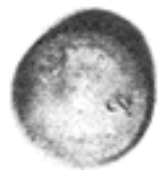

Fig. 8 Specimen repressed

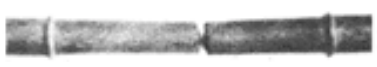

Fig. 9 Traction hot specimen

Plasticity is influenced mostly by: chemical composition, steel microstructure, deformation temperature, deformation speed, deformation degree and the applied state of loads [5].

\section{Conclusions}

A hot plastically deformation study was done for $41 \mathrm{Cr} 4$ ecological steel. Samples were made of hot rolled bars previously manufactured from ingots and respectively billet and hot rolled bars made of continuously casting billet. For plasticity, there were determined: deformation rate $(\varepsilon)$ realized for each temperature at compression (no sample was cracking); deformation to fracture for the tensile test (A).

For the deformation strength there were determined: deformation strength by hot compression $\left(R_{c}\right)$; tensile strength by hot fracture $\left(R_{r}\right)$.

For $41 \mathrm{Cr} 4$ ecological steel the temperature is increasing between $700-1200^{\circ} \mathrm{C}$, and over this margin the temperature is decreasing due to the increase of austenitic grains. The plasticity for billets got from bloom is smaller than that of the bars made of ingot, since casting primary structure has notbeen destroyed yet; However, the plasticity values are high enough (atcompression, the samples made of billet were deformed with $\varepsilon=74.5-85.5 \%$ within the range $800-1500^{\circ} \mathrm{C}$ by a single hammer hit, without cracking) for withstanding hot deformation in order to be further processed into bars or pieces.

\section{References}

1. KULKA M., MAKUCH N., PERTEK A., Optics and Laser Technology 45, 308-318, 2013.

2. RUSANESCU, C. O., RUSANESCU, M., IORDANESCU, T., ANGHELINA, F. V., J ournal of optoelectronics and advanced materials, 15, 7-8, 718 $-723,2013$.

3. KULKA, M, PERTEK, A, Applied Surface Science, 215, Issue 1-4, 278288, 2003.

4. PETRE, I., STOIAN, E.V., ENESCU M.C, Scientific Bulletin of Valahia University-Materials and Mechanics, 14, 11, 35-40, 35-40, 2016.

5. DURBACA, I., STEFANESCU, M.FL., SPOREA, N., Bulletin of the Petroleum-Gas University of Ploiesti, Technical Series, LXV, 1, 64-70, 2013.

6. RUSANESCU, C.O., JINESCU, C., RUSANESCU, M., ENESCU, M. C., ANGHELINA, F. V. STOIAN, E.V., DESPA, V., Mat. Plast., 54, no. 3, 2017, p. $409-413$

7. LORAND, K; CRISTIAN-SORIN, N; ION, D; NICOLAE, F, Solid State Phenomena, Trans Tech Publications, 188, 256-261, 2012.

8. RUSANESCU, C. O., RUSANESCU, M, ANGHELINA F.V., BRATU, V., Romanian Reports in Physics, 68, 1, 278-293, 2016.

9. DURBACA, I., Mat. Plast., 52, no. 1, 2015, p. $43-47$

10. PERTEK, A., KULKA, M.; Applied Surface Science, 205, 1-4, 137$142,2003$.

11.RUSANESCU, C.0., RUSANESCU, M., ANGHELINA, F.V., J. Optoelectron. Adv. Mater. 15, 7-8, 724, 2013.

12. EVANGELISTA, E., MASINI M., EL MEHTEDI, M., SPIGARELLI S., Journal of Alloys and Compounds, 378, 1-2, 151-154, 2004.

13. SOHACIU, M., NICOLAE, A., PREDESCU, CR., VELICU, ST., CALEA, $\mathrm{GH}$., Environmental Engineering and Management J ournal, 8, 4, .997$1001,2009$.

14. KULKA. M., MAKUCH N., PERTEK, A., Optics and laser technology, 45, 308-318, 2013.

15.STOIAN, E.V., BRATU, V., ENESCU, M.C., POPESCU, I.N., The Scientific Bulletin of Valahia University- Materials and Mechanics, 8, 11, 2013.

16. RUSANESCU, C. O., JINESCU, C., PARASCHIV, G., BIRIS, S. ST., RUSÃNESCU, M., GHERMEC, O., Rev. Chim. Bucharest, 66, no. 5, p. 2015, p. 754-757

17. POPESCU, A.M.J., CONSTANTIN, V., OLTEANU, M. DEMIDENKO, 0., YANUSHKEVICH, K., Rev. Chim. (Bucharest) 62, 2011, p. 626

18. POPESCU, I.N., ENESCU, M.C., BRATU, V., ZAMFIR, R.I., STOIAN, E.V., Advanced Materials Research, Trans Tech Publ. 1114, 239-244, 2015.

19. JINESCU, V. V., NICOLOF, V.I., JINESCU, C., CHELU, A., Rev. Chim.(Bucharest), 66, no. 5, 2015, p. 698-702

20. STOIAN, E. V., ENESCU, M. C., PETRE, I., FLUIERARU, P. C., NEGREA, A., Key Engineering Materials, Trans Tech, 750, 39-44, 2017. 21. JINESCU, C., Mat. Plast., 51, no. 3, 2014, p. 235-240,

20. NICOLAE A., NICOLAE M., PREDESCU CR., SOHACIU $M .$, Environmental Engineering and Management Journal, 8, 3, 453456, 2009.

22. JINESCU, V.V., MANEA, S.E., JINESCU, C., Rev. Chim.(Bucharest), 68, no. 4, 2017, p. 656-665,

21. PETRE, I., BRATU, V., ENESCU, M., C., STOIAN, E. V., ANGHELINA, F. V., Key Engineering Materials, Trans Tech, 750, 69-74, 2017.

23. TEODORESCU, N., STEFANESCU, M.F., JINESCU, C., PANAIT, I., Key Engineering Materials 699, 25-30, 2016.

Manuscript received: 22.06 .2018 